\title{
Adapting to climate change at the national level in Caribbean small island developing states
}

\author{
Stacy-ann Robinson \\ Institute at Brown for Environment and Society, Brown University, USA \\ stacy-ann_robinson@brown.edu
}

\begin{abstract}
Small island developing states (SIDS) are distinct from other developing countries: they are particularly and comparatively more vulnerable to the impacts of climate change. Efforts to understand national-level vulnerability in these countries are limited. This paper helps to fill this gap and has two main aims. First, it identifies trends in national-level climate change adaptation among SIDS in the Caribbean region. Second, it identifies the limits to adaptation at the national level in these countries. In applying a resilience lens, and using summative content analysis techniques and semi-structured interviews with 26 senior policy-makers, this paper finds that Caribbean SIDS are primarily adapting to changes in hurricane, rainfall, and drought patterns. It also finds that most adaptations are being undertaken in the coastal zone and the water and agriculture sectors, and that there are many factors limiting national-level adaptation. The most commonly reported limit is financing, though not all policy-makers agree that financing is a limit. These findings are important for national SIDS governments and international donors and agencies that will be better able to identify and fill gaps in their adaptation actions and financing. This paper's findings also highlight the importance of depoliticising climate change and prioritising good governance, improving SIDS' access to international adaptation financing, and making the road to a climate-resilient future by walking.
\end{abstract}

Keywords: adaptation, Caribbean, climate change, finance, limits, resilience, small island developing states (SIDS), trends

https://doi.org/10.24043/isj.59

(C) 2018 - Institute of Island Studies, University of Prince Edward Island, Canada.

\section{Introduction}

Small island developing states (SIDS) are distinct from other developing countries: they are particularly and comparatively more vulnerable to the impacts of climate change. However, they are vulnerable in different ways and have vastly different capacities for effective climate change adaptation and resilience building. Their uniqueness and diversity are, however, acknowledged in a range of international policy documents relating to environment and development. These include the 1992 United Nations Framework Convention on Climate Change (UNFCCC), the 1994 Barbados Programme of Action for the Sustainable Development of SIDS, and the 2015 Paris Climate Agreement.

Chapter 29 of the Fifth Assessment Report of the Intergovernmental Panel on Climate Change (AR5) reconfirms that, "Given the inherent physical characteristics of small islands, the high level of vulnerability of small islands to multiple stressors, both climate and nonclimate" exists (Nurse et al., 2014, p. 1616). These vulnerabilities, understood as "the propensity or predisposition to be adversely affected" (IPCC, 2014, p. 1775), span economic, social, political, and environmental domains. They are inextricably linked to adaptive 
capacity, or the "ability of systems, institutions, humans, and other organisms to adjust to potential damage, to take advantage of opportunities, or to respond to consequences" (IPCC, 2014, p. 1758). As a result, climate change adaptation is an important component of sustainable development in SIDS (Robinson, 2017).

Adaptation is probably best understood as "the process of adjustment to actual or expected climate and its effects. In human systems, adaptation seeks to moderate or avoid harm or exploit beneficial opportunities. In some natural systems, human intervention may facilitate adjustment to expected climate and its effects" (IPCC, 2014, p. 1758). At the national level, therefore, governments and other actors with country-wide reach and influence contribute to, participate in, and/or facilitate the required adjustments across multiple sectors (see, e.g., Berrang-Ford et al., 2011; Pauw, 2014). The extent to which national SIDS governments can successfully implement adaptations will influence the sustainability of development pathways in these countries.

Though there is no official list of SIDS, the United Nations Office of the High Representative for the Least Developed, Landlocked Developing Countries and the Small Island Developing States (UN-OHRLLS) identifies 58 SIDS across three main geographic regions - 29 of these are located in the Caribbean. Only 16 of the 29 Caribbean SIDS have United Nations membership.

Box 1: List of Caribbean SIDS. (Based on UN-OHRLLS, 2011; symbols are explained in the Methods section of this paper.)

\begin{tabular}{|c|c|}
\hline 1. Anguilla ${ }^{+}$ & 16. Guyana ${ }^{\star \#+}$ \\
\hline 2. Antigua and Barbuda ${ }^{\star \#+}$ & 17. Haiti $^{+}$ \\
\hline 3. Aruba $^{+}$ & 18. Jamaica ${ }^{\star \#+}$ \\
\hline 4. Bahamas ${ }^{\#+}$ & 19. Martinique ${ }^{+}$ \\
\hline 5. Barbados $^{+}$ & 20. Montserrat \\
\hline 6. Belize $\mathrm{e}^{\star \#+}$ & 21. Puerto Rico $^{+}$ \\
\hline 7. Bermuda $^{+}$ & 22. Sint Maarten \\
\hline 8. British Virgin Islands & 23. St. Kitts and Nevis ${ }^{+}$ \\
\hline 9. Cayman Islands ${ }^{+}$ & 24. St. Lucia ${ }^{\star \#+}$ \\
\hline 10. $\mathrm{Cuba}^{+}$ & 25. St. Vincent and the Grenadines \\
\hline 11. Curacao & 26. Suriname ${ }^{+}$ \\
\hline 12. Dominica ${ }^{\star \#+}$ & 27. Trinidad and Tobago ${ }^{\star \#+}$ \\
\hline 13. Dominican Republic ${ }^{+}$ & 28. Turks and Caicos Islands \\
\hline 14. Grenada ${ }^{+}$ & 29. United States Virgin Islands ${ }^{+}$ \\
\hline 15. Guadeloupe & \\
\hline
\end{tabular}

Chapter 29 of AR 5 synthesises the key climate vulnerabilities of and impacts for small islands, including those in the Caribbean. Four of these impacts are highlighted here. The first impact is sea-level rise. Drawing on work by Palanisamy et al. (2012), for example, the Report confirms that sea-level rise in the Caribbean between 1950 and 2009 was similar to the rising global average: approximately $1.8 \mathrm{~mm}$ per year. The second impact is an increase in the intensity of tropical and extratropical cyclones. The Report uses research by Cambers (2009) to attribute higher beach erosion rates in the Caribbean to higher incidence of hurricanes. Between 1985 and 2000, the average yearly rates of beach erosion were $0.5 \mathrm{~m}$. Increased beach erosion rates are also connected to issues of human impact on changing coastlines. For example, work by Schleupner (2008) supported conclusions about physical infrastructure impeding the natural retreat of wetlands and beaches. The third impact is increasing air and sea surface temperatures, which trigger coral bleaching events. The Report draws on research by Oxenford et al. (2007) to show the extensive impacts of such events: up to $70 \%$ of corals were bleached following a Caribbean-wide event in 2005. The fourth 
impact is changing rainfall patterns. Caribbean rainfall records between 1900 and 2000, studied by Jury and Winter (2010) and cited by the Report, reveal a consistent $0.18 \mathrm{~mm}$ annual reduction in rainfall. Changing rainfall patterns have an impact on island freshwater variability and availability in the Caribbean (Cashman et al., 2010). These key climate vulnerabilities and impacts, as well as the region's dependence on income-generating sectors such as tourism and fisheries, heighten the importance of avoiding management failures in a SIDS context (see Clayton, 2009; Mycoo, 2007, 2014; Pantin, 1999).

This paper focuses on national-level adaptation in Caribbean SIDS. This focus is important, as it provides an opportunity for actors at other scales (i.e., subnational and supranational) to identify gaps in government action and to form the basis for cooperative action. This study differs from previous studies such as Day et al. (2016), Roson (2014), and CARIBSAVE Partnership (2012), which focus on assessing climate variability, modelling climate impacts, and developing risk profiles, respectively. This paper has two main aims. First, it identifies trends in how SIDS in the Caribbean region are adapting to climate change at the national level. Second, it identifies the limits to adaptation at the national level in these countries. In order to achieve these aims, the remainder of the paper is organised into six sections. The first section reviews the academic literature. The second explains the theoretical framework, and the third describes the methods. The fourth and fifth sections present the results and then discuss them. The sixth and final section summarises this paper's main contributions to the literature.

\section{Literature review}

There is limited academic research that substantially examines climate change and adaptation in Caribbean SIDS. This section reviews 17 peer-reviewed articles, reviews, and book chapters retrieved from a systematic search of Scopus ${ }^{\circledR}$, an academic database, on March 15, 2017 (the time of writing). The inclusion of four key words ("climat AND "small island" AND "Caribbean") appearing in article titles, abstracts, and key words retrieved six results (the use of the asterisk accommodated words with different stems). An expanded search using three key words ("climat` change" AND "adapt" AND "Caribbean") retrieved 36 results. From this, 19 results were excluded because they were either not peerreviewed $(N=2)$, not written in English $(N=2)$, or because their titles or abstracts were not relevant $(N=4$ and $N=11$, respectively). Figure 1, below, presents an illustrated summary of the 17 publications included in this review. They are organised by publication year (see Part A), system of focus (see Part B), topic (see Part C), and case study country (see Part D).

Based on the Scopus ${ }^{\circledR}$ search results, academic research into climate change and adaptation in Caribbean SIDS is generally increasing, and tends to focus on climate impacts and adaptations in human systems. In general, research uses multi-country $(>2)$ case studies. This section provides a brief summary of the relevant articles from the Scopus ${ }^{\circledR}$ search. It does not intend to give a comprehensive overview of all the literature relating to climate change adaptation in SIDS. Instead, it takes a systematic approach to highlighting the gaps in the literature that relate specifically to Caribbean SIDS. 

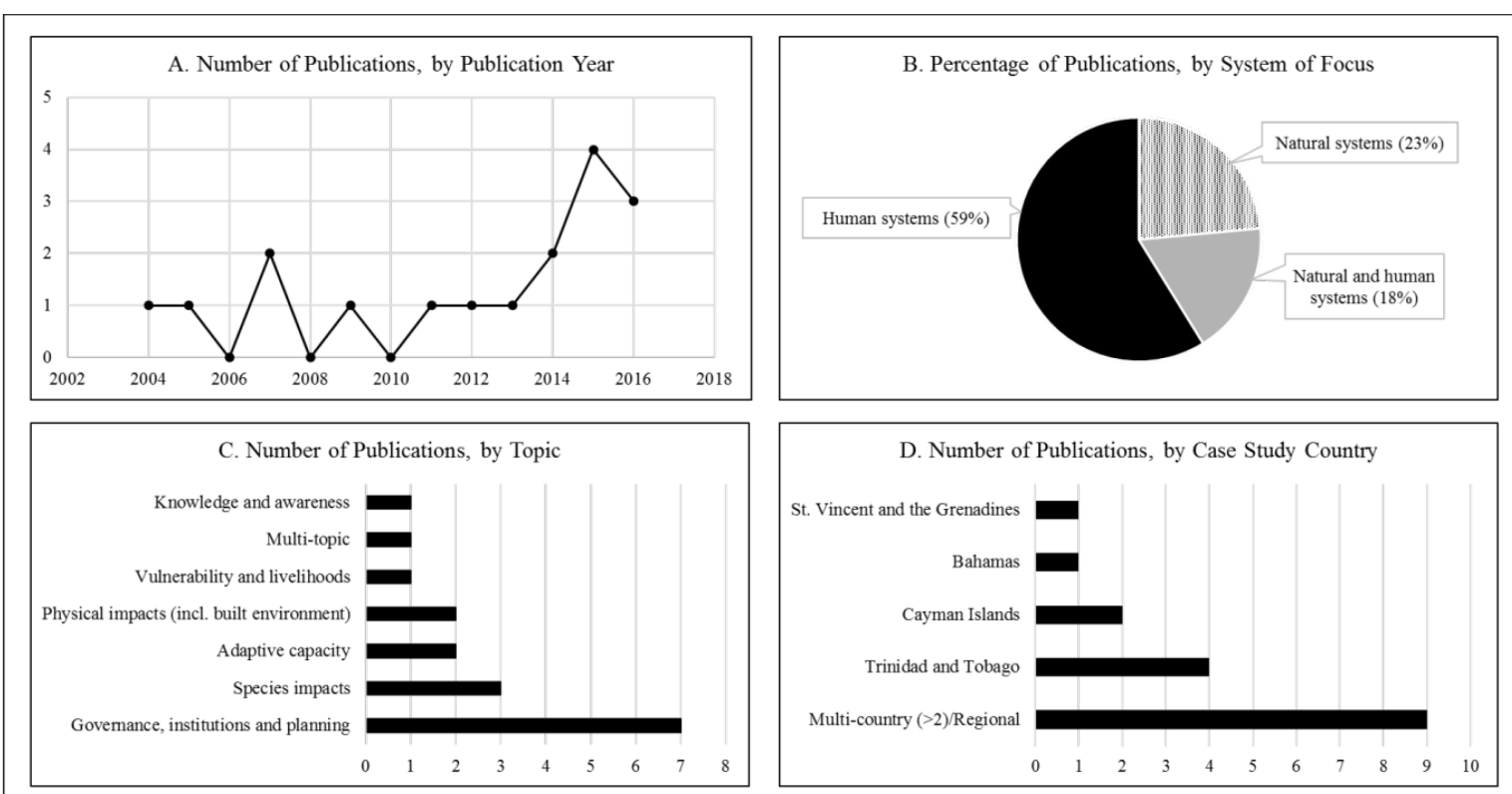

Figure 1: Illustrated summary of the literature on climate change and adaptation in Caribbean SIDS. (C Stacy-ann Robinson)

The main topic across the 17 peer-reviewed articles, reviews, and book chapters is the governance of, as well as institutions and planning for, climate change and adaptation in Caribbean SIDS. This is the focus of seven publications (41\%) (see Part C in Figure 1). Adger et al. (2011, p. 760) examine hurricanes as system stressors in the Cayman Islands, particularly citing "recurrent exposure to hazards within living memories" and the "experiences of neighboring countries" as revealing the "importance of preparedness." They further examine the sources of resilience, active responses to hazards, and the effects of these responses on resilience, discussing the role and importance of prioritising infrastructure, logistics, governance, and active learning in recovery processes. The authors observe "sensitivity to the impacts of policy responses" alongside a "high level of flexibility in future responses, which are continually evolving" (Adger et al., 2011, p. 762). Hughes (2013, p. 570) emphasises the role people play in accelerating climate change and their "responsibility, complicity, and culpability" in this regard. Mahon and Fanning (2016, p. 107) acknowledge the role of extraregional environmental change on ocean governance in the region, and argue that effective ocean governance must be appropriately positioned in the international arena as well as "contribute to the emerging governance structure, and learn from what is working, and not working, in other regions." Based on their studies of informal urban settlements in Trinidad and Tobago, Middelbeek et al. (2014, p. 143) suggest that "A proper analysis of CC [climate change] governance, therefore, requires an institutional examination that focuses on internal processes, external relationships, and linkages with different social groups and households." Robinson (2017) provides a global outlook of adaptation actions in SIDS, but with little focus on Caribbean SIDS. Robinson and Gilfillan (2017) zero in on the adaptation-related inputs, outputs, and projects/programs of the Caribbean Community Climate Change Centre (CCCCC or 5Cs), which is the "key node for information on climate change issues and on the region's response to managing and adapting to climate change in the Caribbean" (CCCCC, 2015, online). Based on their study of adaptive capacities at the household level in Trinidad and Tobago, Shah and Dulal (2015, p. 1379) recommend that SIDS policymakers "consider food security in light of climate variability and related weather-induced impacts." Tompkins (2005, p. 139) studies storm risk in the Cayman Islands, concluding that "self-efficacy, strong local and international support networks, combined with a willingness to act collectively and to learn from mistakes appear to have increased the resilience." 
The issue of governing climate change in Caribbean SIDS is connected to knowledge, vulnerability, livelihoods, and adaptive capacity. Rawlins et al. (2007) capture the variations in knowledge, attitudes, and practices (KAPs) towards climate change, as well as impacts detection and attribution in Trinidad and Tobago and St. Kitts and Nevis. Work by Smith and Rhiney (2016) underscores the sensitivity and exposure of Indigenous communities to climate-related hazards, and draws attention to the role of economic and political factors in driving vulnerability. Tompkins and Adger (2004) support building resilience as a way to cope with environmental change, and their study demonstrates a positive relationship between community-based management and adaptive capacity.

Other related articles focus on the impacts of climate change on both the physical environment and various species. Beach monitoring conducted as part of a study by Cambers (2009) shows upward trends in beach erosion across eight islands. Donner et al. (2007) examine the effects of warmer seas on a major coral bleaching event in the Caribbean, while Muñoz et al. (2014) and Thorpe et al. (2015) focus on tropical lizards. Muñoz et al. (2014, p. 1) "discuss how exposure to selection on physiology influences divergence among tropical organisms and its implications for adaptive evolutionary response to climate warming," and Thorpe et al. (2015) suggest that anthropogenic climate change may not be as big a threat on the species (as opposed to invasive alien species or habitat loss, for example) due to their rapid evolution. Rockwellet al. (2012) study migratory birds in the Bahamas and find that "firsttime breeders were much more sensitive to changes in rainfall than experienced adults" and that the drying trend in the Caribbean would result in fewer offspring. Vergara et al. (2015) quantify loss and damage from the physical impacts of climate change in a number of sectors in Latin America and the Caribbean, including agriculture, health, and marine and terrestrial ecosystems. Though their estimates also include Latin America, their work puts a price tag of US\$85-\$110 million per year on climate-related loss and damage up to 2050 .

\section{Theoretical framework}

This paper, following the work of Adger et al. (2011), applies a resilience lens to understanding how Caribbean SIDS are adapting to climate change at the national level and the factors that are potentially limiting this adaptation. Because of the uncertainties associated with climate change as well as the uncertainties in adaptive capacities (see, e.g., Adger \& Vincent, 2005; Foley, 2010), Barnett (2001) zeroes in on a small island context and suggests the need for a "complementary strategy aimed to enhance the resilience of whole island socialecological systems" (emphasis added). Though resilience is a contested term-it has been varyingly defined in the literature (Bahadur et al., 2010; Saxena et al., 2017) — this paper understands it as "The capacity of social, economic, and environmental systems to cope with a hazardous event or trend or disturbance, responding or reorganizing in ways that maintain their essential function, identity, and structure, while also maintaining the capacity for adaptation, learning, and transformation" (IPCC, 2014, p. 1772). Resilience is underpinned by sustainable development, and is seen as a process along a continuum. This process is not necessarily linear, though often depicted as such (building on Manyena, 2006) (see Figure 2, below). It is further seen as having an opposite relationship with 'vulnerability' and being similar to 'adaptive capacity' (following Osbahr, 2007). According to Hay (2013, p. 309), "Vulnerability [and adaptive capacity] and resilience are considered to be important integrating concepts when managing the local consequences of global changes." As a result, many adaptation actions are geared towards reducing vulnerability and increasing adaptive capacities and resilience through improving climate-related knowledge and "strengthening socio-economic systems and livelihoods" (Hay, 2013, p. 309). "Managing global change can be closely aligned with local development [...] processes" (Hay, 2013, p. 309) (also Gallopín, 2006; McEvoy et al., 2013). This will enhance "the overall sustainability of development 
processes and outcomes" (Hay, 2013, p. 309). In applying a resilience lens, however, this paper makes a number of assumptions. These include that countries are required to respond to climate impacts, and that they aim to reduce their vulnerabilities and increase their resilience to these impacts. Furthermore, viewing resilience and vulnerability as polar opposites may not acknowledge the possibility of a country being resilient to one impact, yet vulnerable to another (Bahadur et al., 2010).

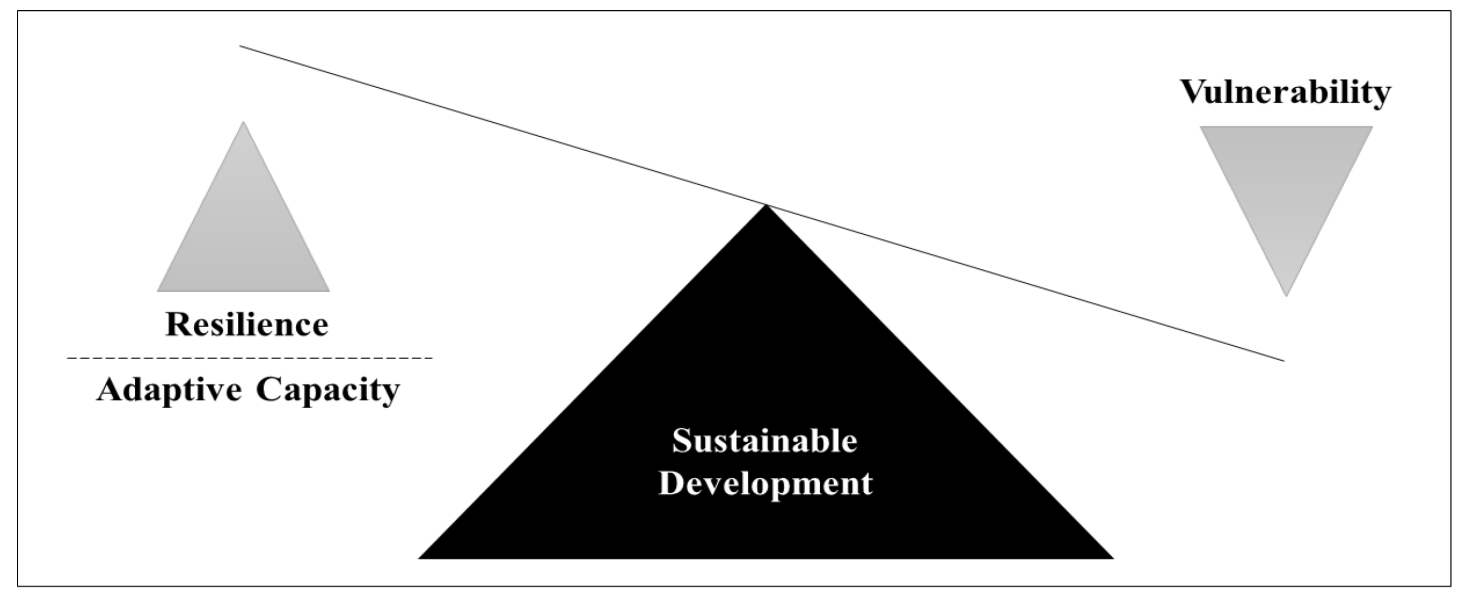

Figure 2: A conceptualisation of resilience, vulnerability and adaptive capacity. (C) Stacyann Robinson)

\section{Methods}

This paper replicates the methods outlined in Robinson (2017) and generates results for adaptation trends in Caribbean SIDS. It considers seven countries (24\% of the 29 Caribbean SIDS and 44\% of the 16 Caribbean SIDS with United Nations membership): Antigua and Barbuda, Belize, Dominica, Guyana, Jamaica, St. Lucia, and Trinidad and Tobago. These countries are denoted by an asterisk, “*, in Box 1 above. Summative content analysis techniques were applied to the adaptation-related chapters in countries' Initial or Second National Communication to the UNFCCC Secretariat that were submitted in English before December 31, 2014. National Communications (1) are considered official government documents and contain their climate change policies, (2) detail the adaptation actions undertaken by them, and (3) are important for understanding more about the climatic and climate-related vulnerabilities and adaptive capacities of reporting countries (following Lesnikowski et al., 2015). Each relevant chapter was read twice. National-level adaptation actions were manually coded, counted, and compared according to the vulnerabilities, sectors, and actors described. Incomplete actions were not coded.

A sample of eight countries was used to investigate climate change adaptation limits in Caribbean SIDS: the seven named in the preceding paragraph plus the Bahamas, which submitted its Second National Communication in 2015. These countries are denoted by a hash sign, '\#', in Box 1 above. Summative content analysis techniques were again applied to these countries' Initial or Second National Communication to the UNFCCC Secretariat, where these were submitted in English before December 31, 2015 (i.e., up to one year after the first analysis of adaptation trends was done). Each relevant chapter was read twice. The occurrence of the word 'limit' alongside or in relation to one or more of six other key words and their variants - 'adapt', 'barrier', 'constrain', 'obstacle', 'risk' and 'threat' (per Klein et al., 2014) — was counted and compared.

Like Betzold and Weiler (2017) and Robinson and Dornan (2017), this paper further uses the Rio Climate Markers database to identify trends in bilateral adaptation financing from Members of the Organisation of Economic Co-operation and Development (OECD), a 
major donor, but exclusively to Caribbean SIDS. Data for 23 Caribbean SIDS (79\% of all 29 Caribbean SIDS) are considered (indicated by a plus sign, '+', in Box 1 above): Anguilla, Antigua and Barbuda, Aruba, Bahamas, Barbados, Belize, Bermuda, Cayman Islands, Cuba, Dominica, Dominican Republic, Grenada, Guyana, Haiti, Jamaica, Martinique, Puerto Rico, St. Kitts and Nevis, St. Lucia, St. Vincent and the Grenadines, Suriname, Trinidad and Tobago, and the United States Virgin Islands. The Rio Climate Markers track financing for climate adaptation, climate mitigation, biodiversity, and desertification actions (OECD, 2011). Results are presented by year, score (i.e., whether adaptation funds principally or significantly supported adaptation), and individual OECD donors.

Alongside these results are the findings from semi-structured interviews with 26 Caribbean policy-makers working with national governments in Jamaica and St. Lucia, and with regional organisations such as the CCCCC. Email invites were sent to 66 national and regional policy-makers. The names of potential interviewees were derived from the UNFCCC website and from official government documents. The response rate was 39\%. Interviewees were representative of the total population: they were senior in their respective organisations, directly responsible for environment and development portfolios, available during the interview period, and willing to participate in the interviews. Interviews were undertaken in person or via Skype teleconferencing between August 2014 and July 2016, and focused on policy-makers' views on adaptation trends and limits. Interview audio was listened to twice and manually coded, paying particular attention to emerging themes. Direct quotes are used to illustrate key points and are attributable to a specific interviewee by way of a unique identifier (e.g., ID01, which represents the first interviewee) so as to conceal their identities.

The selected methods have limitations. First, using National Communications as a data source to understand trends in and limits to climate change adaptation is not ideal as these Reports may be prone to under- and/or over-reporting. Further, only United Nations Member States are required to produce them. Of the 29 SIDS in the Caribbean, only 16 (or 55\%) are United Nations Member States, which impacts the various country sample sizes used in this study. Despite this, National Communications are currently the most consistent source of nationally reported, national-level adaptation actions across developing countries (Lesnikowski et al., 2015). Second, many of the interviewees were Jamaican policy-makers, which is largely due to the comparatively large size of the Jamaican civil service, the availability of potential interviewees, and their interest in participating in the study. This could be a potential source of bias in the data. However, this was partially offset by the fact that many interviewees were also regional policy-makers, representing a diverse range of countries from across the region. Third, the Rio Markers system has been criticised for facilitating donors tagging 'regular' development financing as climate financing without meeting their obligation to provide additional financing for climate action (see, e.g., Stadelmann et al., 2011). Additionally, the collection of climate financing data as part of the Rio Markers system has a relatively short history (from 2010 onwards) - compared to financing for biodiversity, for example, which limits the extent of longitudinal analyses that can be carried out. Despite this, the System is acknowledged as one of the most comprehensive datasets currently available (Betzold \& Weiler, 2017).

\section{Results}

Trends in climate change adaptation in Caribbean SIDS

Four hundred and sixty-two national-level adaptation actions were counted across the National Communications of the seven Caribbean SIDS sampled. Incomplete actions were not counted. The single most commonly reported action was vulnerability and impact assessments, which accounted for $10 \%$ of adaptation actions. This was followed by adaptation research, as well as workshops and training, which accounted for $9 \%$ each. In terms of the 
climate-induced vulnerabilities that the named actions were addressing, countries reported responding most to non-exclusive changes in hurricanes and storm surge/coastal inundation (12\% each; of instances where climate-induced vulnerabilities were indicated), rainfall (11\%), air and sea surface temperatures (10\%), and drought conditions (10\%). In terms of addressing non-climate-induced vulnerabilities, countries reported responding most to non-exclusive economic constraints $(22 \%$ of instances where non-climate-induced vulnerabilities were indicated), social factors (9\%), the impacts of recreational and development activities (7\%), and pollution and waste (6\%). National governments reported being most non-exclusively engaged with other country governments (i.e., through bilateral relations) ( $26 \%$ of actions), with regional and sub-regional organisations (22\%), and with inter-governmental/ international organisations (18\%). By sector, the highest number of adaptations were reported in the coastal zone and the environment (not otherwise classified) $(12 \%$ each; of instances where sectors were indicated). This was followed by actions in the forestry and agriculture $(11 \%)$, tourism $(10 \%)$, and water $(9 \%)$ sectors. Adaptations in the finance sector accounted for $7 \%$. No adaptations in the social sector were reported.

When asked about adaptations that were being undertaken in the region, most interviewees were able to quickly list public education and awareness activities along with stakeholder consultations. Examples included radio, TV and print campaigns, the training of journalists, and interfaces with primary and secondary schools (e.g., logo competitions) (e.g., ID04-05, ID13-14). Adaptation research was also an important activity. In Jamaica, for example, a survey of the public's KAPs towards climate change was conducted in 2012, with the hope of the activity being repeated every three years (ID13). Another example was a costbenefit analysis conducted for a mobile desalination project in St. Lucia (ID26). Interviewees also cited the development, review, and analysis of climate change policies (ID08, ID13, ID14-16, ID26). This included the mainstreaming of climate change considerations into sectoral policies for water, forestry, tourism, industry and commerce, and disaster risk reduction (ID01, ID04, ID05, ID13, ID26). Some interviewees spoke to organisational changes such as the creation of a Climate Change Division in Jamaica (ID08-12, ID14), which is believed to be the only country in the region to establish a clear climate change focus in its government (ID14). Only three interviewees mentioned vulnerability and adaptation assessments (ID08, ID14, ID26).

There was consensus among interviewees that many adaptations in the Caribbean were being undertaken in the water and agriculture sectors. One interviewee pointed out that vulnerable sectors were identified in countries' Initial National Communication to the UNFCCC and that governments have been working to reduce climate vulnerabilities in these sectors (ID08). In the case of Jamaica, these sectors were water, agriculture, human health, and coastal resources (including human settlements) (ID08). With respect to coastal resources, one official underscored that:

Over $60 \%$ of Jamaica's population is located in the coastal area-almost the entire landscape is vulnerable. The economy is so dependent on coastal resources. If a major hurricane comes, the whole economy would crash. (ID01)

Other sectors of focus include forestry, fisheries, and tourism (e.g., ID01, ID19, ID26). Three interviewees also mentioned adaptations in the energy sector, but noted that these actions were not being undertaken solely because of climate change (ID14, ID19, ID26). According to one of the three interviewees, "Energy for us is not just about climate change. It's about economics" (ID19).

In terms of climate-induced vulnerabilities, most interviewees identified sea-level rise as the most critical climate change impact for Caribbean SIDS (e.g., ID01, ID13, ID26). One interviewee further questioned the implications of sea-level rise for land resources, 
communities, social services, livelihoods, and the people (ID13). Interviewees also mentioned the intensity of storms and other natural disasters (e.g., ID04, ID05, ID08, ID19). Only one interviewee identified ocean acidification as a climate impact, but was quick to note that the issue was an emergent one and not much was known about the science behind the phenomenon or the policy responses that would be required (ID14).

All interviewees agreed that countries in the region face a myriad of non-climateinduced vulnerabilities that were thought to be impeding the achievement of sustainable development. One official shared that:

The National Security Policy identified 90 threats to Jamaica [...] The impact of crime in Jamaica is fifteen times higher than that of earthquakes. The cost of crime is $7.5 \%$ of the country's GDP [...] A hurricane costs [the country] 2\% of GDP every couple or few years but the high probability-high impact events are crime and corruption. These do more harm than any other threat. (ID24)

Also on the perceived enormity of the threat of crime and corruption on the region's development, another official noted that:

Eight out of the ten most violent countries in world are in the LAC [Latin America and Caribbean] region. The extent of the problem is actually quite horrendous. (ID25)

These views suggest that the most pressing non-climate-induced vulnerability in Caribbean SIDS could, in fact, be social in nature.

Limits to climate change adaptation in Caribbean SIDS

Across the National Communications of the eight Caribbean SIDS sampled (Antigua and Barbuda, Bahamas, Belize, Dominica, Guyana, Jamaica, St. Lucia, and Trinidad and Tobago), 202 limits to national-level adaptation were counted. Incomplete actions were not counted. In rank order, countries mostly reported being limited non-exclusively by (1) finances, budgetary restrictions, and income (15\%); (2) technical capacity and resources (10\%); (3) data and records (8\%); (4) natural resources and features (6\%); (5) human resources, manpower, and turnover (6\%); (6) knowledge and understanding of climate effects, especially (to be) gained through research (5\%); (7) the focus or scope of national policies, legislation, and regulations (4\%); (8) monitoring and evaluation, and enforcement capacity (3\%); (9) size (3\%); and (10) public education and awareness (3\%). The least commonly reported non-exclusive limits were land arability and soil chemistry, the social acceptability of the adaptations proposed and undertaken, and the frequency and intensity of climate impacts. Figure 3, below, contains the full results for the eight countries. 


\begin{tabular}{|c|c|c|}
\hline No. & Adaptation Limit & Total Counts \\
\hline 1 & Finance e.g. government expenditure & 31 \\
\hline 2 & Technical capacity/resources & 21 \\
\hline 3 & Data/records & 16 \\
\hline 4 & Natural resources/features (availability of/dependence on) & 13 \\
\hline 5 & Human resources/manpower/turnover & 12 \\
\hline 6 & Knowledge/understanding (of climate effects; gained through research) and expertise & 10 \\
\hline 7 & National focus/policy/legislation and regulations & 8 \\
\hline 8 & Monitoring and evaluation/enforcement capacity & 7 \\
\hline 9 & Size (including population) & 6 \\
\hline 10 & Public education (including formal), awareness, knowledge, 'ownership' & 6 \\
\hline 11 & Poor inter-agency communication/coordination & 5 \\
\hline 12 & Individual limits/preferences & 5 \\
\hline 13 & Nature and diversity of impacts & 5 \\
\hline 14 & Limited capacity to adapt & 4 \\
\hline 15 & Modelling software/models & 4 \\
\hline 16 & Natural hazards & 4 \\
\hline 17 & Land area/availability/use & 4 \\
\hline 18 & Opportunities/options/choice & 3 \\
\hline 19 & Mainstreaming (disaster risk reduction and/or adaptation into development) & 3 \\
\hline 20 & Facilities/equipment e.g. medicine storage/hurricane shelters & 3 \\
\hline 21 & Existing infrastructure & 3 \\
\hline 22 & Response capability & 3 \\
\hline 23 & Markets/economic structures & 3 \\
\hline 24 & Sector productivity & 3 \\
\hline 25 & Environmental conditions/management/natural thresholds & 3 \\
\hline 26 & Technological & 2 \\
\hline 27 & Capacity to manage & 2 \\
\hline 28 & Cost and other effect & 2 \\
\hline 29 & (Re)insurance & 2 \\
\hline 30 & Stakeholder participation & 2 \\
\hline 31 & Culture & 1 \\
\hline 32 & Perceptions & 1 \\
\hline 33 & Social acceptability & 1 \\
\hline 34 & International law e.g. limits of the Exclusive Economic Zone & 1 \\
\hline 35 & Socio-economic conditions & 1 \\
\hline 36 & Frequency/intensity of impacts & 1 \\
\hline 37 & Land arability/soil chemistry & 1 \\
\hline
\end{tabular}

Figure 3: Limits to climate change adaptation in Caribbean SIDS. (C) Stacy-ann Robinson, as reported in National Communications)

Most interviewees agreed that financing and organisational capacity are two of the major limits to adaptation in Caribbean SIDS (e.g., ID13, ID14, ID19, ID26). According to one official, "Limits in the Caribbean context deal with economics and growth" (ID26). Some SIDS, such as Jamaica, have an "air-tight fiscal space because of the IMF Agreement" (ID13). Another interviewee stated:

Every year the budget is cut and you're told to survive on what you've been givenmost of the funding is project funding. We rely heavily on project funding, which comes with conditions. You might know the ideal way [of implementing a project successfully] but the money comes with conditions. (ID01)

Some officials agreed that financing may be a secondary issue. One official said, "A lot of the times, it is some of the other institutional or organisational issues that are causing the problem" (ID08). Two officials, in particular, were outspoken in disagreeing that financing is a major adaptation limit in Caribbean SIDS. One of these officials stated: 
Small island states in the Caribbean first need to look at governance before we start talking about finance [...] Finance is not our major impediment. If we are not properly structured internally, our institutions are too politicised or they are not working the way they ought to work then it doesn't matter how much monies we pour or throw at the problem, the problem will not be solved. I am saying clearly that our biggest challenge is not climate change. It's governance [...] All you need to do is check the Transparency International Index to see the level of corruption [across the region] and where our countries rate along that Index. It wouldn't make for pretty reading. (ID19)

With respect to organisational capacity, one civil servant stated, "Skilled labour in the Caribbean is always migrating. We can't stop migration but we sure can slow it down" (ID19). Two other civil servants noted, respectively, that:

Research capacity is so limited across the Caribbean. Investment is less than $1 / 2 \%$ of GDP. $1 \frac{1}{2}$ to $2 \frac{1}{2} \%$ of GDP is what countries with good capacities are spending. The University of Sao Paolo is in the top 200 universities. UWI [University of the West Indies] is not even in the top 1,000. There are universities but they primarily teach. Although there are pockets of research excellence, the capacity is really low. (ID24)

'Oh, I think' or 'Oh, I suppose' are phrases we use a lot—knowledge management is a real challenge in SIDS. (ID26)

Officials raised a number of other factors, including the small size of islands. Of particular concern was the role that the region's socio-political culture plays in limiting adaptation action. One official, referencing the nature of the public's relationship with politicians, noted, "In the Caribbean, we have a culture of dependency, not independence" (ID26). Another official, specifically referencing Jamaica, explained that the "politics of patronage" "was introduced in 1972" (ID24). ID01 gave a telling example of this:

Persons are living in vulnerable locations. But it's really hard to get them to move. You face resistance from MPs and Councillors indirectly. They don't want you to relocate them because they will lose votes [if electoral populations change]. They want you to mitigate even though relocation is the best option. It's a bigger problem than you think.

Similar to the results in the previous section, these views suggest that non-finance-related factors such as poor governance, corruption, and socio-political culture are potentially playing an equal or greater role in limiting adaptation in Caribbean SIDS.

\section{Climate change adaptation financing to Caribbean SIDS}

Fifteen Caribbean SIDS received US $\$ 824$ million worth of commitments from Members of the OECD between 2010 and 2014. These countries were Antigua and Barbuda, Barbados, Belize, Cuba, Dominica, Dominican Republic, Grenada, Guyana, Haiti, Jamaica, St. Kitts and Nevis, St. Lucia, St. Vincent and the Grenadines, Suriname, and Trinidad and Tobago. These recipient countries account for 65\% of the 23 aid-receiving Caribbean SIDS and for $52 \%$ of all 29 Caribbean SIDS.

Over the period, total commitments generally increased. Commitments were lowest in 2010 (US\$60 million) with a dip from 2011 to 2012 (US\$115 million) and highest in 2014 (US\$355 million) (see Figure 4A, below). Significant adaptation financing (US $\$ 492$ million) outpaced principal adaptation financing (US\$331 million), with total significant financing 
over the period accounting for $60 \%$ of total financing (see Figure $4 \mathrm{~B}$, below). In these cases, though adaptation was a significant objective, the project had "other prime objectives" or had been "formulated or adjusted to help meet climate concerns" (OECD, 2011, p. 2). Where adaptation was the principal objective, the project would not "have been funded but for that objective" (OECD, 2011, p. 2).

Of the 15 recipient countries, the top five were (in rank order) Dominican Republic, Haiti, Guyana, Jamaica, and Cuba. Together, commitments to these countries accounted for $88 \%$ of total commitments to Caribbean SIDS. The Dominican Republic received the largest commitment of principal financing over the period (US\$222 million), which accounted for $67 \%$ of total principal financing to the region. This commitment of principal financing to the Dominican Republic was also 500\% more than that committed to Haiti, which received the second largest commitment of principal financing (US\$37 million) (see Figure 4C, below). Both Haiti and Guyana received the largest commitments of significant financing over the period (US $\$ 164$ million and US $\$ 144$ million, respectively). Barbados and Trinidad and Tobago received the smallest commitments, totalling US\$0.1 million, which was 339\% less than Antigua and Barbuda (US\$0.6 million), the country receiving the third smallest commitments over the period. Barbados and Trinidad and Tobago only received principal financing.

The top five individual donors to the region, in rank order, were France, European Union (EU) institutions (e.g., the European Investment Bank and other European multilaterals), Norway, Spain, and United States (see Figure 4D, below). Together, they made up $79 \%$ of the total commitments to the region. France made the largest commitment to the Dominican Republic; Norway to Guyana; and EU institutions to Jamaica.
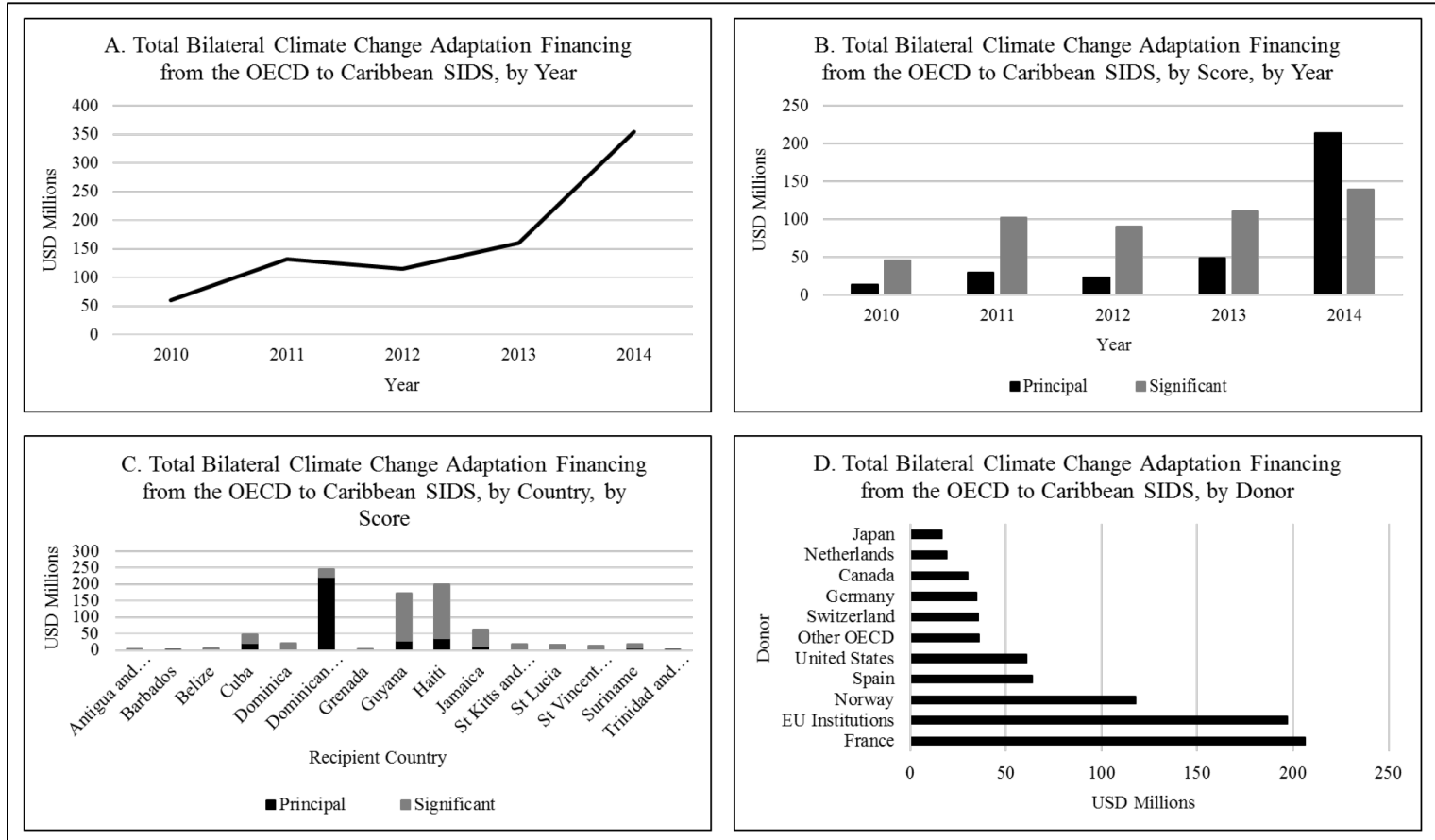

Figure 4: Total climate change adaptation financing from Members of the Organisation of Economic Co-operation and Development to sampled Caribbean SIDS, 2010-2014. (C) Stacy-ann Robinson; based on OECD, 2015)

Interviewees acknowledged that access to international adaptation financing is a challenge for Caribbean SIDS and argued that most countries required support: 
Some SIDS are quite poor. [But] not all developing countries will require support e.g., Singapore [...] Trinidad and Tobago, which is rich in oil, Bahamas with [its] strong economy. But some countries are overwhelmed e.g., Jamaica, Guyana and Barbados and a lot of the countries in the Pacific and we need to have the support. (ID08)

Considering the demand side of adaptation financing in SIDS, "Programs and policies are driven by financing" (ID14). But there are some countries such as the Bahamas that "cannot access some funding sources because of their economic classification [as a high-income economy]" (ID13). Also, "some of the countries accessing loans [for climate change adaptation] already have a high debt burden" (ID13). These and related issues aside, one civil servant said:

There are some things that you can do without a lot of money. The countries that don't have a climate policy in place, for example [...] it's a poor excuse to say that you don't have the money to do it. Yes, it may require an expert at some point $[\ldots]$ and in some cases, if you really want to get finance to do something like that, it is available but countries don't take advantage of it. (ID08)

Considering the supply side, one interviewee acknowledged that "grant funding is not flowing as freely as was promised" (ID14). This could be the case for a number of reasons. Two possibilities are given here. First, according to one interviewee:

We had some success with the Adaptation Fund in how that was assisting countries with their adaptation needs. The source of the Fund has dried up somewhat as it was dependent on the carbon market. The price of carbon has gone way down and the market is no longer functioning as it should. (ID08)

And second:

Some international organisations would prefer to funnel funds through regional organisations because of the varied management of those funds in various jurisdictions. (ID13)

Connected to this idea, one interviewee said that regional "organisations such as the 5Cs are largely donor-driven. Donors decide what they can and can't fund and where they can and can't work" (ID19). These issues aside, one policy-maker noted:

Attempts are being made to better structure finance with the GCF [Green Climate Fund]. New funds are now friendlier to developing countries. Direct access allows you to do away with all the executing agencies. (ID08)

These views suggest that policy-makers in the Caribbean have many concerns relating to international adaptation financing. These include country eligibility for financing, and fluctuations in the carbon market, which are affecting the availability of grant financing. Despite these concerns, policy-makers acknowledge that new funds such as the GCF are more developing-country-friendly and that monies are indeed available to help SIDS develop adaptation policies and programs, once they seek them out. 


\section{Discussion}

Depoliticising climate change and prioritising good governance in Caribbean SIDS

This study's analysis of countries' National Communications to the UNFCCC reveals that reported climate change adaptation limits are mainly finance-related. This is largely supported by the interview data, though some policy-makers do not agree that financing is a limit. The study also highlights a mismatch between the perceived social limits to adaptation and the amount of social adaptations being undertaken-Caribbean SIDS reported neither social adaptations nor adaptations in the social sector. Where social adaptations are concerned, it is important to target the right issues (Larson, 2010). In the case of the Caribbean, interviews suggest that these concerns relate to depoliticising climate change and prioritising good governance. Interviewees highlighted the historical role that politics plays in thwarting efforts towards environmental sustainability in the region, even though "climate change is long range and politics [i.e., the political cycle] is every five years" (ID01). Authors such as Smith and Rhiney (2016) draw attention to the role of political factors in driving vulnerability, which must be circumvented if climate change is to be depoliticised. Interviewees spoke of, for example, resistance from Members of Parliament when the relocation of constituents from vulnerable locations is required (ID01). They also spoke of the "politics of patronage" that has been a feature of Jamaican public life since the 1970s (ID24). One policy-maker acknowledged, "We're slowly getting government buy-in but both sides [i.e., Government and Opposition] need to agree" (ID01). This has not been helped by the fact that "There is a perception among private sector and other stakeholders that climate change is the [responsibility of the] Government" (ID14), which points to misperceptions about roles and responsibilities as well as the need to increase stakeholder awareness. Ford and King (2015) and Sherman and Ford (2013) also draw attention to the importance of broad stakeholder engagement in adaptation actions at various scales. Additionally, in the Caribbean, "Governments prefer to articulate strategies from an economic perspective rather than a climate change perspective" (ID26), and policy-makers "are trying to emphasise that climate change is not an environment challenge but a development challenge" (ID19).

In view of the above points, "Priming the governance system for climate change adaptation" in Caribbean SIDS is crucial (Baird et al., 2014, p. 1). For Middelbeek et al. (2014, p. 143), "A proper analysis of CC [climate change] governance, therefore, requires an institutional examination that focuses on internal processes, external relationships, and linkages with different social groups and households." While a detailed institutional analysis is beyond the scope of this paper, a number of broad perspectives on governance can be deduced from the interviews conducted as part of this study. ID19, for example, referenced the Caribbean's sub-optimal performance on Transparency International's Corruption Perceptions Index. The 2016 Index results reveal that the Caribbean may not entirely be a poor performer. The Bahamas ranks fourth best in the Americas, behind Canada, the United States, and Uruguay, and $24^{\text {th }}$ in the world (Transparency International, 2017). The results also show that, of the 13 Caribbean SIDS sampled, perceptions of corruption in the Dominican Republic and Haiti were the worst (see Figure 5, below). Comparing these results to 2014, perceptions in five countries had improved (Cuba, Dominica, Haiti, Jamaica, and Suriname), but worsened in six (the Bahamas, Barbados, the Dominican Republic, Guyana, St. Vincent and the Grenadines, and Trinidad and Tobago). Though perceptions are not always a reflection of reality, the results indicate that there is still work to be done. 


\begin{tabular}{|c|l|c|c|c|c|}
\hline No. & \multicolumn{1}{|c|}{ Country } & 2016 Rank & 2016 Score & 2014 Score & $\begin{array}{c}\text { Comparison } \\
\text { (2014 vs. 2016) }\end{array}$ \\
\hline 1 & Bahamas & 24 & 66 & 71 & - \\
\hline 2 & Barbados & 31 & 61 & 74 & - \\
\hline 3 & St. Lucia & 35 & 60 & - & - \\
\hline 4 & St. Vincent and the Grenadines & 35 & 60 & 67 & - \\
\hline 5 & Dominica & 38 & 59 & 58 & \\
\hline 6 & Grenada & 46 & 56 & - & - \\
\hline 7 & Cuba & 60 & 47 & 46 & - \\
\hline 8 & Suriname & 64 & 45 & 36 & - \\
\hline 9 & Jamaica & 83 & 39 & 38 & - \\
\hline 10 & Trinidad and Tobago & 101 & 35 & 38 & - \\
\hline 11 & Guyana & 108 & 34 & 30 & - \\
\hline 12 & Dominican Republic & 120 & 31 & 32 & - \\
\hline 13 & Haiti & 159 & 20 & 19 & \\
\hline
\end{tabular}

Figure 5: Corruption Perceptions Index-Caribbean SIDS. (C) Stacy-ann Robinson; based on Transparency International, 2017)

Improving access to international adaptation financing for Caribbean SIDS

This study finds that finances account for $15 \%$ of adaptation limits reported by Caribbean SIDS in their National Communications. One interviewee, however, admitted:

We know a lot of that money is going to waste. 10\% of the population [in Jamaica] pays income tax. There is a lot of tax evasion. There's a reason why the government has no money. (ID01)

The study further confirms, through an analysis of OECD data, that $67 \%$ of total principal adaptation financing to the region was committed to one country: the Dominican Republic. This suggests that many Caribbean SIDS are missing out on principal financing. It also shows that allocations across SIDS are skewed, a conclusion also drawn by Betzold and Weiler (2017) and Donner et al. (2016), who study adaptation financing, primarily to Pacific SIDS. So why is this the case in the Caribbean? First, some countries may be more adept at securing funds. One civil servant noted that "If you don't use the words 'climate change', you won't get the funding" (ID01), hinting at the idea that environment and/or development project proposals are being labelled as climate change projects as a way of attracting funding. Second, some countries may be better organised than others. According to another civil servant, "We don't have dedicated funding in St Lucia as in Jamaica with a dedicated Climate Change Ministry [at the time]Jamaica is one of the few countries that have been able to do that" (ID14). Third, some countries may not be able to meet donors' co-financing requirements, meaning that entire grant amounts do not, in fact, trickle down to recipient countries. As one official explained:

There are tensions between the COP [i.e., the UNFCCC Conference of the Parties] and the GEF [Global Environment Facility] Council regarding their requirements for in-kind and monetary contributions. Also, when they take a percentage as management fees. So you can't hire the most competent people and some countries had to 'top up' the amounts for management. (ID08)

Considering the points above, what can Caribbean SIDS do to improve their access to international climate change adaptation financing? Some policy-makers suggested that governments across the region need to change their way of thinking (ID01, ID05-06, ID1920, ID23-26). Connected to this is the view that: 
You can't do little micro projects. You have to think big disasters now. We have to think with bigger ideas to get the money and the problem is that everybody wants to see results now and climate change is a long range thing. (ID01)

But, more broadly, how can access be improved? Afful-Koomson (2015) and Bird (2014), among others, explore a range of options that deal primarily with the structure of international funds such as the GCF. For interviewees, the type of financing available (i.e., grants vs loans) is key: there is a strong preference for grant financing. According to one interviewee, "Grants ... that is what we will need to help us" (ID13). Another consideration is the economic classification of Caribbean SIDS. Twelve of the 29 Caribbean SIDS (41\%) are currently listed as high-income economies by the World Bank, meaning they have a per capita gross national income (GNI) that exceeds US $\$ 12,475$ (World Bank, 2016). These countries are Antigua and Barbuda, the Bahamas, Barbados, Bermuda, the British Virgin Islands, the Cayman Islands, Puerto Rico, Sint Maarten, St. Kitts and Nevis, Trinidad and Tobago, Turks and Caicos Islands, and the United States Virgin Islands (World Bank, 2016). The other 16 countries, except Haiti, are all upper-middle-income economies (55\%) with a per capita GNI of between US $\$ 4,036$ and $\$ 12,475$ (World Bank, 2016). Haiti is a low-income economy, earning less than US $\$ 1,025$ per capita (World Bank, 2016). One interviewee highlighted that countries such as the Bahamas "cannot access some funding sources because of their economic classification" (ID13). Also, "some of the countries accessing loans [for climate change adaptation] already have a high debt burden" (ID13). While per capita income has been shown to be positively correlated with the volume of aid received (see, e.g., Feeny \& McGillivray, 2010; Wall, 1995), the interrelated and complex nature of the vulnerabilities of SIDS needs to be taken into account in allocation decisions rather than basing these primarily on national incomes.

Making the road (to a climate-resilient future in Caribbean SIDS) by walking

This study finds that policy-makers in Caribbean SIDS generally recognise the need to build resilience into natural and human systems in order to adequately adapt to climate change (e.g., ID01, ID10-11, ID15-16, ID21-22). Tompkins and Adger (2004) support building resilience as a way to cope with environmental change. Building resilience, however, may be easier said than done: Adger et al. (2011, p. 762) observe "sensitivity to the impacts of policy responses" alongside the "high level of flexibility in future responses, which are continually evolving." Despite this, increasing resilience in a SIDS context is possible. However, can the same be said for a climate-resilient future? One interviewee suggested "making the road by walking" (ID26), mimicking the name of a 2014 book by Brian McLaren, which offers "a simple curriculum of insightful reflections and transformative practices" for a "reintroduction to Christian faith" (emphases added) (McLaren, 2014, p. xi). Interviewees had some insightful reflections and suggestions for transformative practices, which, following Adger et al. (2011), could be seen as sources of or platforms for building a climate-resilient future.

For some policy-makers, the quest for resilience and sustainable development has both advantages and disadvantages; officials called it a "catch 22" (ID02-03, ID24-26):

The whole idea of resilience is that you build redundancy and independence into the system [...] In Jamaica, if power goes down, our water system also goes down. In the quest for modernity, we stopped relying on springs in local communities and started pumping water, which requires power. It just doesn't make any sense. (ID24) 
Another official shared that:

Instead of importing all of these [climate adaptation] strategies, we should focus on home-grown strategies. We need to think about food security and the principle of equifinality [i.e., that there are many means to the same end]. (ID26)

The latter view aligns with the literature that focusses on incorporating local and traditional knowledge into adaptation. Mercer et al. (2014) specifically examine this in the context of food security in Atlantic and Indian Ocean SIDS. The authors find a lack of coherence in "approaching food security, in terms of policies and actions not reflecting the ecosystemfood-climate nexus" and "the infrequency with which knowledge integration occurs" (Mercer et al., 2014, p. 5566) (see also Shah and Dulal, 2015). Further, London (2004, p. 491), in discussing the implications of climate change for 12 Caribbean SIDS, acknowledges more broadly the need for an "institutional and managerial framework that incorporates dynamic change into individual and collective decision-making processes." While "Some countries are better organised than others" (ID19), it is important to "look for 'win-win' options that reduce exposure and build resilience" (ID01). These "win-win' options include "Not making climate change the sole issue" (ID01), developing and using "a matrix for top priorities [e.g., a probability impact matrix] [to] determine how and what to respond to" (ID24), and noting that:

The key is how we do planning and regulation. We need to think about our centres of human population, transportation. We need a master plan. (ID01)

\section{Conclusion}

This paper had two aims. First, it identified trends in how SIDS in the Caribbean region are adapting to climate change at the national level. Second, it identified the phenomena seen as the primary limits to adaptation at the national policy level in these countries. In applying a resilience lens and using summative content analysis techniques and semi-structured interviews with 26 senior policy-makers, this paper found that Caribbean SIDS are mostly adapting to changes in hurricane, rainfall, and drought patterns, and that most adaptations are being undertaken in the coastal zone, water, and agriculture sectors. It further found that there are many factors limiting national-level adaptation: the most commonly reported limit is financing, though not all policy-makers agree that financing is a limit. These findings are important for national SIDS governments and international donors and agencies that will be better able to identify and fill gaps in their adaptation actions and financing. This paper's findings will also help them to better understand the perspectives of policy-makers on these issues.

\section{Acknowledgements}

The author would like to acknowledge fieldwork funding from the Fenner School of Environment and Society at The Australian National University; helpful comments from the anonymous reviewers; and proofreading and editing support from Sonya Gurwitt.

\section{References}

Adger, W.N., Brown, K., Nelson, D.R., Berkes, F., Eakin, H., Folke, C., Galvin, K., Gunderson, L., Goulden, M., O'Brien, K., Ruitenbeek, J., \& Tompkins, E.L. (2011). 
Resilience implications of policy responses to climate change. Wiley Interdisciplinary Reviews: Climate Change, 2(5), 757-766. https://doi.org/10.1002/wcc.133

Adger, W.N., \& Vincent, K. (2005). Uncertainty in adaptive capacity. Comptes Rendus Geoscience, 337(4), 399-410. https://doi.org/10.1016/j.crte.2004.11.004

Afful-Koomson, T. (2015). The Green Climate Fund in Africa: what should be different? Climate and Development, 3(4), 367-379. https://doi.org/10.1080/17565529.2014.951015

Bahadur, A., Ibrahim, M., \& Tanner, T. M. (2010). The resilience renaissance? Unpacking of resilience for tackling climate change and disasters. Brighton: Institute of Development Studies.

Baird, J., Plummer, R., \& Pickering, K. (2014). Priming the governance system for climate change adaptation: The application of a social-ecological inventory to engage actors in Niagara, Canada. Ecology and Society, 19(1), 1-11. https://doi.org/10.5751/ES_$\underline{06152-190103}$

Barnett, J. (2001). Adapting to climate change in Pacific island countries: The problem of uncertainty. World Development, 29(6), 977-993. https://doi.org/10.1016/S0305750X(01)00022-5

Berrang-Ford, L., Ford, J.D., \& Paterson, J. (2011). Are we adapting to climate change? Global Environmental Change, 21(1), 25-33. https://doi.org/10.1016/j.gloenvcha.2010.09.012

Betzold, C., \& Weiler, F. (2017). Allocation of aid for adaptation to climate change: Do vulnerable countries receive more support? International Environmental Agreements: Politics, Law and Economics, 17(1), 17-36. https://doi.org/10.1007/s10784-016-9343$\underline{8}$

Bird, N. (2014). Improving access to international climate finance within sub-Saharan Africa. London: Overseas Development Institute.

Cambers, G. (2009). Caribbean beach changes and climate change adaptation. Aquatic Ecosystem Health \& Management, $12(2)$, 168-176. https://doi.org/10.1080/14634980902907987

CARIBSAVE Partnership (2012). CARIBSAVE climate change risk profile for Jamaica. Christ Church, Barbados: CARIBSAVE Partnership.

Cashman, A., Nurse, L., \& John, C. (2010). Climate change in the Caribbean: the water management implications. The Journal of Environment \& Development, 19(1), 42-67. https://doi.org/10.1177/1070496509347088

CCCCC (2015). About CCCCC. Caribbean Community Climate Change Centre. http://www.caribbeanclimate.bz/about-us/about-us.html

Clayton, A. (2009). Climate change and tourism: the implications for the Caribbean. Worldwide Hospitality and Tourism Themes, 1(3), 212-230. https://doi.org/10.1108/17554210910980576

Day, O., van Proosdij, D., Campbell, D., Lee, S., Baker, G., \& Thomas, J. (2016). Building capacity for coastal ecosystem-based adaptation in small island developing states (SIDS): assessing climate vulnerability in Grenada and responding with coastal ecosystem-based adaptation action. Nairobi: CARIBSAVE Partnership.

Donner, S.D., Knutson, T.R., \& Oppenheimer, M. (2007). Model-based assessment of the role of human-induced climate change in the 2005 Caribbean coral bleaching event. Proceedings of the National Academy of Sciences of the United States of America, 104(13), 5483-5488. https://doi.org/10.1073/pnas.0610122104

Donner, S.D., Kandlikar, M., \& Webber, S. (2016). Measuring and tracking the flow of climate change adaptation aid to the developing world. Environmental Research Letters, 11(5), 1-9. https://doi.org/10.1088/1748-9326/11/5/054006 
Feeny, S., \& McGillivray, M. (2010). Aid and growth in small island developing states. The journal of development studies, 46(5), 897-917. https://doi.org/10.1080/00220381003623889

Foley, A.M. (2010). Uncertainty in regional climate modelling: a review. Progress in Physical Geography, 34(5), 647-670. https://doi.org/10.1177/0309133310375654

Ford, J.D., \& King, D. (2015). A framework for examining adaptation readiness. Mitigation and Adaptation Strategies for Global Change, 20(4), 505-526. https://doi.org/10.1007/s11027-013-9505-8

Gallopín, G.C. (2006). Linkages between vulnerability, resilience, and adaptive capacity. Global Environmental Change, 293-303. https://doi.org/10.1016/j.gloenvcha.2006.02.004

Hay, J.E. (2013). Small island developing states: coastal systems, global change and sustainability. Sustainability Science, 8(3), 309-326. https://doi.org/10.1007/s11625013-0214-8

Hughes, D.M. (2013). Climate change and the victim slot: From oil to innocence. American Anthropologist, 115(4), 570-581. https://doi.org/10.1111/aman.12044

IPCC (2014). Annex II: Glossary. In V.R. Barros, C.B. Field, D.J. Dokken, M.D. Mastrandrea, K.J. Mach, T.E. Bilir, M. Chatterjee, K.L. Ebi, Y.O. Estrada, R.C. Genova, B. Girma, E.S. Kissel, A.N. Levy, S. MacCracken, P.R. Mastrandrea, \& L.L. White (Eds.) Climate change 2014: Impacts, adaptation, and vulnerability. Part B: Regional aspects. Contribution of Working Group II to the Fifth Assessment Report of the Intergovernmental Panel on Climate Change (pp. 1757-1776). Cambridge \& New York: Cambridge University Press.

Jury, M.R., \& Winter. A. (2010). Warming of an elevated layer over the Caribbean. Climatic Change, 99(1), 247-259. https://doi.org/10.1007/s10584-009-9658-3

Klein, R.J.T., Midgley, G.F., Preston, B.L., Alam, M., Berkhout, F.G.H., Dow, K., \& Shaw, M.R. (2014). Adaptation opportunities, constraints, and limits. In V.R. Barros, C.B. Field, D.J. Dokken, M.D. Mastrandrea, K.J. Mach, T.E. Bilir, M. Chatterjee, K.L. Ebi, Y.O. Estrada, R.C. Genova, B. Girma, E.S. Kissel, A.N. Levy, S. MacCracken, P.R. Mastrandrea, \& L.L. White (Eds.) Climate change 2014: Impacts, adaptation, and vulnerability. Part B: Regional aspects. Contribution of Working Group II to the Fifth Assessment Report of the Intergovernmental Panel on Climate Change (pp. 899-943). Cambridge \& New York: Cambridge University Press.

Larson, S. (2010). Understanding barriers to social adaptation: are we targeting the right concerns? Architectural Science Review, 53(1), 51-58. https://doi.org/10.3763/asre.2009.0103

Lesnikowski, A.C., Ford, J.D., Berrang-Ford, L., Barrera, M., \& Heymann, J. (2015). How are we adapting to climate change? A global assessment. Mitigation and Adaptation Strategies for Global Change, 20(2), 277-293. https://doi.org/10.1007/s11027-0139491-X

London, J.B. (2004). Implications of climate change on small island developing states: experience in the Caribbean region. Journal of Environmental Planning and Management, 47(4), 491-501. https://doi.org/10.1080/0964056042000243195

Mahon, R., \& Fanning, L. (2016). Linking Caribbean ocean governance efforts to global arrangements. Social and Economic Studies, 65(1), 107-130.

Manyena, S.B. (2006). The concept of resilience revisited. Disasters, 30(4), 434-450. https://doi.org/10.1111/j.0361-3666.2006.00331.x

McEvoy, D., Fünfgeld, H., \& Bosomworth, K. (2013). Resilience and climate change adaptation: The importance of framing. Planning Practice \& Research, 28(3), 280-293. https://doi.org/10.1080/02697459.2013.787710 
McLaren, B. (2014). We make the road by walking: a year-long quest for spiritual formation, reorientation, and activation. New York: Jericho.

Mercer, J., Kelman, I., Do Rosario, F., De Deus de Jesus Lima, A., Da Silva, A., Beloff, A.M., \& McClean, A. (2014). Nation-building policies in Timor-Leste: Disaster risk reduction, including climate change adaptation. Disasters, 38(4), 690-718. https://doi.org/10.1111/disa.12082

Middelbeek, L., Kolle, K. \& Verrest, H. (2014). Built to last? Local climate change adaptation and governance in the Caribbean: the case of an informal urban settlement in Trinidad and Tobago. Urban Climate, 8(0), 138-154. https://doi.org/10.1016/j.uclim.2013.12.003

Muñoz, M.M., Stimola, M.A., Algar, A.C., Conover, A., Rodriguez, A.J., Landestoy, M.A., Bakken, G.S., \& Losos, J.B. (2014). Evolutionary stasis and lability in thermal physiology in a group of tropical lizards. Proceedings of the Royal Society B: Biological Sciences, 281(1778), 1-9. https://doi.org/10.1098/rspb.2013.2433

Mycoo, M. (2014). Sustainable tourism, climate change and sea level rise adaptation policies in Barbados. Natural Resources Forum, 38(1), 47-57. https://doi.org/10.1111/1477$\underline{8947.12033}$

Mycoo, M. (2007). Diagnosis of Trinidad's water problems (mid-1980s to mid-1990s). Water Policy, 9(1), 73-86. https://doi.org/10.2166/wp.2006.062

Nurse, L.A., McLean, R.F., Agard, J., Briguglio, L.P., Duvat-Magnan, V., Pelesikoti, N., Tompkins, E., \& Webb, A. (2014). Small islands. In V.R. Barros, C.B. Field, D.J. Dokken, M.D. Mastrandrea, K.J. Mach, T.E. Bilir, M. Chatterjee, K.L. Ebi, Y.O. Estrada, R.C. Genova, B. Girma, E.S. Kissel, A.N. Levy, S. MacCracken, P.R. Mastrandrea, \& L.L. White (Eds.) Climate change 2014: Impacts, adaptation, and vulnerability. Part B: Regional aspects. Contribution of Working Group II to the Fifth Assessment Report of the Intergovernmental Panel on Climate Change (pp. 1613-1654). Cambridge \& New York: Cambridge University Press.

OECD (2015). Official development assistance-definition and coverage. Organisation for Economic Co-operation and Development. http://www.oecd.org/dac/stats/officialdevelopmentassistancedefinitionandcoverage.htm

OECD (2011). Trade openness. Organisation for Economic Co-operation and Development. http://www.oecd-ilibrary.org/

Osbahr, H. (2007). Building resilience: adaptation mechanisms and mainstreaming for the poor. In Human Development Report 2007/2008-fighting climate change: human solidarity in a divided world. New York: United Nations Development Programme.

Oxenford, H.A., Roach, R., Brathwaite, A., Nurse, L., Goodridge, R., Hinds, F., Baldwin, K., \& Finney, C. (2007). Quantitative observations of a major coral bleaching event in Barbados, Southeastern Caribbean. Climatic Change, 87 (3), 435. https://doi.org/10.1007/s10584-007-9311-y

Palanisamy, H., Becker, M., Meyssignac, B., Henry, O., \& Cazenave, A. (2012). Regional sea level change and variability in the Caribbean sea since 1950. Journal of Geodetic Science, 2(2), 125-133. https://doi.org/10.2478/v10156-011-0029-4

Pantin, D.A. (1999). The challenge of sustainable development in small island developing states: case study on tourism in the Caribbean. Natural Resources Forum, 23(3), 221233. https://doi.org/10.1111/j.1477-8947.1999.tb00911.x

Pauw, W.P. (2014). Not a panacea: private-sector engagement in adaptation and adaptation finance in developing countries. Climate Policy, 15(5), 583-603. https://doi.org/10.1080/14693062.2014.953906

Rawlins, S.C., Chen, A., Rawlins, J.M., Chadee, D.D., \& Legall, G. (2007). A knowledge, attitude and practices study of the issues of climate change/variability impacts and public health in Trinidad and Tobago, and St. Kitts and Nevis. West Indian Medical Journal, 56(2), 115-121. 
Robinson, S. (2017). Climate change adaptation trends in small island developing states. Mitigation and Adaptation Strategies for Global Change, 22(4), 669-691. https://doi.org/10.1007/s11027-015-9693-5

Robinson, S., \& Dornan, M. (2017). International financing for climate change adaptation in small island developing states. Regional Environmental Change, 17(4), 1103-1115. https://doi.org/10.1007/s10113-016-1085-1

Robinson, S., \& Gilfillan, D. (2017). Regional organisations and climate change adaptation in small island developing states. Regional Environmental Change, 17(4), 989-1004. https://doi.org/10.1007/s10113-016-0991-6

Rockwell, S.M., Bocetti, C.I., \& Marra, P.P. (2012). Carry-over effects of winter climate on spring arrival date and reproductive success in an endangered migratory bird, Kirtland's $\begin{array}{lllll}\text { warbler (Setophaga } \quad \text { Kirtlandii). } & \text { 7uk, }\end{array}$ https://doi.org/10.1525/auk.2012.12003

Roson, R. (2014). Development of a modelling framework in support of an assessment of the economic and social impacts of climate change in the Caribbean. In ECLAC-Studies and Perspectives Series-the Caribbean. Santiago: United Nations Economic Commission for Latin American and the Caribbean.

Saxena, A., Qui, K., \& Robinson, S. (2017). Knowledge, attitudes and practices of climate adaptation actors towards resilience and transformation in a $1.5^{\circ} \mathrm{C}$ world. Environmental Science \& Policy, 1-8. https://doi.org/10.1016/j.envsci.2017.11.001

Schleupner, C. (2008). Evaluation of coastal squeeze and its consequences for the Caribbean island Martinique. Ocean \& Coastal Management 51(5), 383-390. https://doi.org/10.1016/j.ocecoaman.2008.01.008

Shah, K.U., \& Dulal, H.B. (2015). Household capacity to adapt to climate change and implications for food security in Trinidad and Tobago. Regional Environmental Change, 15(7), 1379-1391. https://doi.org/10.1007/s10113-015-0830-1

Sherman, M.H., \& Ford, J. (2013). Stakeholder engagement in adaptation interventions: an evaluation of projects in developing nations. Climate Policy, 14(3), 417-441. https://doi.org/10.1080/14693062.2014.859501

Smith, R.A.J., \& Rhiney, K. (2016). Climate (in)justice, vulnerability and livelihoods in the Caribbean: the case of the indigenous Caribs in northeastern St. Vincent. Geoforum, 73(0), 22-31. https://doi.org/10.1016/j.geoforum.2015.11.008

Stadelmann, M, Timmons Roberts, J., \& Michaelowa, A. (2011). New and additional to what? Assessing options for baselines to assess climate finance pledges. Climate and Development, 3(3), 175-192.

Thorpe, R.S., Barlow, A., Malhotra, A., \& Surget-Groba, Y. (2015). Widespread parallel population adaptation to climate variation across a radiation: Implications for adaptation to climate change. Molecular Ecology, 24(5), 1019-1030. https://doi.org/10.1111/mec.13093

Tompkins, E.L., \& Adger, W.N. (2004). Does adaptive management of natural resources enhance resilience to climate change? Ecology and Society, 9(2), 1-14.

Tompkins, E.L. (2005). Planning for climate change in small islands: Insights from national hurricane preparedness in the Cayman Islands. Global Environmental Change, 15(2), 139-149.

Transparency International (2017). Corruption Perceptions Index 2016. Transparency International.

http://www.transparency.org/news/feature/corruption perceptions index 2016\#t able

UN-OHRLLS (2011). Small island developing states: Small island, big(ger) stakes. New York: United Nations Office of the High Representative for the Least Developed Countries, Landlocked Developing Countries and Small Island Developing States. 
Vergara, W., Rios, A.R., Galindo, L.M., \& Samaniego, J. (2015). Physical damages associated with climate change impacts and the need for adaptation actions in Latin America and the Caribbean. In W.L. Filho (Ed.) Handbook of climate change adaptation (pp. 479-491). Berlin: Springer-Verlag Berlin Heidelberg.

Wall, H.J. (1995). The allocation of official development assistance. Journal of Policy Modeling 17(3), 307-314. https://doi.org/10.1016/0161-8938(94)00031-A

World Bank (2016). World Bank country and lending groups. World Bank, accessed May 3, 2017. https://datahelpdesk.worldbank.org/knowledgebase/articles/906519-worldbank-country-and-lending-groups 